IRA-International Journal of Management \& Social Sciences

ISSN 2455-2267; Vol.06, Issue 01 (2017)

Pg. no. 91-96

Institute of Research Advances

http://research-advances.org/index.php/RAJMSS

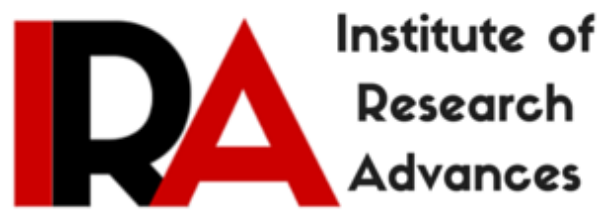

\title{
Financial Inclusion-Role of Payment Banks in India
}

\author{
Dr. G. Sabitha Srinivas \\ (MBA, M.Phil, Ph.D.) \\ Associate Professor \& HoD \\ School of Business Management, \\ Anurag Group of Institutions, India.
}

Type of Review: Peer Reviewed.

DOI: http://dx.doi.org/10.21013/jmss.v6.n1.p12

\section{How to cite this paper:}

Srinivas, G. (2017). Financial Inclusion-Role of Payment Banks in India. IRAInternational Journal of Management \& Social Sciences (ISSN 2455-2267), 6(1), 91-96. doi:http://dx.doi.org/10.21013/jmss.v6.n1.p12

(C) Institute of Research Advances

\section{(cc) EY-NC}

This work is licensed under a Creative Commons Attribution-Non Commercial 4.0 International License subject to proper citation to the publication source of the work.

Disclaimer: The scholarly papers as reviewed and published by the Institute of Research Advances (IRA) are the views and opinions of their respective authors and are not the views or opinions of the IRA. The IRA disclaims of any harm or loss caused due to the published content to any party. 


\section{ABSTRACT}

Opening of new branch in every village is uneconomical for any traditional bank. Transactions through mobile phones may cover a low cost platform for basic banking services to every rural or urban citizen. India's domestic remittance market is more than Rs. 900 Billions. The payment banks play a vital role in implementing the government's direct benefit transfer scheme, where subsidies on healthcare, education and gas are paid directly to beneficiaries' accounts. Keeping in mind the government's unwavered digital drive target, customers shifting from cash transactions to operating their accounts on their mobile phone, this paper discusses the objectives of primary banks, its history and services rendered by it. This paper also focuses on m-Banking, the Department of Posts, Pradhan Mantri Jan-Dhan Yojana and the India Post Payments Banks.

Keywords: IPPB, M-Banking, Payment banks, PMJDY, RBI.

\section{Introduction:}

Payments banks are a new model of banks conceptualised by the Reserve Bank of India (RBI). These banks can accept a restricted deposit which is currently limited to INR 1 lakh per customer and may be increased further. These banks cannot issue loans and credit cards. Both current account and savings accounts can be operated by such banks. Payments banks can issue services like ATM cards, debit cards, online banking and mobile banking. Airtel has launched India's first live payments bank. Paytm is the second such service to be launched in the country.

Payments Banks will magnify the potential of financial inclusion in the economy. It will empower those citizens who have only transacted in cash, to head towards formal banking. Traditional banks may be hesitant to open branches in every village due to its uneconomic returns, but simple mobile phone coverage is all that is required now.

India also serves as a big remittance market and with money transfers possible through mobile phones, workers and migrant labours could simply shift to Payments Bank and send their money home.

\section{Objectives of payments banks:}

The payments banks are given the status of scheduled banks under the section 42 (6) (a) of the Reserve Bank of India Act, 1934.

The primary objectives of payment banks are to increase the restricted holding of maximum balance of Rs. 1 lakh per individual customers under small savings accounts and to provide payments and remittance services to unorganized sectors.

\section{History:}

23 September 2013: Committee on Comprehensive Financial Services for Small Businesses and Low Income Households was formed by the RBI headed by Nachiket Mor.

7 January 2014: the Nachiket Mor committee submitted its final report with various recommendations including the formation of a new category of bank called payments bank.

17 July 2014: the RBI released the draft guidelines for payment banks, seeking comments for interested entities and the general public.

27 November: RBI released the final guidelines for payment banks. 
In February 2015, RBI released the list of entities which had applied for a payments bank license. There were 41 applicants. It was also announced that an external advisory committee (EAC) headed by Nachiket Mor would evaluate the license applications.

28 February 2015: during the presentation of the Budget it was announced that India Post will use its large network to run payments bank.

6 July 2015: the external advisory committee submitted its findings. The applicant entities were examined for their financial track record and governance issues.

19 August 2015: the Reserve Bank of India gave "in-principle" licenses to eleven entities to launch payments banks out of these 3 were surrendered. The remaining 8 entities are listed below:

1. Aditya Birla Nuvo

2.Airtel M Commerce Services

3. Department of Posts

4.FINO PayTech

5.National Securities Depository

6. Reliance Industries

7.Paytm

8. Vodafone M-Pesa

The RBI will consider grant full licenses under Section 22 of the Banking Regulation Act, 1949, after it is satisfied that the conditions have been fulfilled.

\section{Payment System:}

A payment system is any system used to settle financial transactions through the transfer of monetary value, and includes the institutions, instruments, people, rules, procedures, standards, and technologies that make such an exchange possible. A common type of payment system is the operational network that links bank accounts and provides for monetary exchange using bank deposits.

A payments bank cannot lend or give advance to customers. It can issue cheque books and debit cards. It will not issue any credit card.

\section{Services of Payment banks:}

The payments bank can set up their outlets such as branches, Automated Teller Machines (ATMs), Business Correspondents (BCs), etc. which will be regulated by the Banking Regulation Act, 1949. The services which are to be considered for regulations are:

Small deposit accounts: Accepts Demand deposits and savings bank deposits from any individuals and other small firms. NRI deposits will not be accepted under this account. The mobilised deposits would be insured under DICGC to a holding of maximum balance of Rs. 100,000 per individual. The payments bank also needs to comply with its own KYC norms.

Issuance of ATM / Debit Cards: Payments banks will not issue credit cards as per the RBI guidelines because they will not deal with lending businesses.

Payments and remittance services: Payments can be transferred through branches, Automated Teller Machines (ATMs), Business Correspondents (BC), mobile banking and can be accessed through point of sales terminals adhering to the terms and conditions that card payments network should be authorized 
with debit card payments other than credit card, regulated under the PSS Act. Utility bills and any other payments can be done through payments bank app.

Cross-border remittance services: With the prior approval of RBI, the banks can handle cross-border remittance transactions if they are in nature of personal payments/remittances on the current account.

Internet Banking: The RBI is also open to payments bank offering Internet banking services. The payments bank is expected to offer low-cost banking solutions. Such a bank should ensure that it has all systems enabled so that in the third party service providers, any kind of fraudulent activities if occurs, can be controlled to enable offering transactional services on the internet. The payments bank can accept remittances to be sent to or receive payments from multiple banks under a payment mechanism approved by RBI, which are RTGS / NEFT / IMPS.

Financial Services: Payments banks can further deal with the non-risk sharing simple financial services activities, including Mutual fund units, insurance products, pension policies, etc adhering to terms and conditions imposed by RBI.

\section{Chain effect of Cash less economy:}

1. Credit access and financial inclusion: Improvement in credit access and financial inclusion will benefit the growth of Small Medium Enterprises s in the medium and long run.

2. Tax Avoidance: Higher traceability of all the transactions can reduce the tax avoidance and money laundering.

3. Carrying Cash: The increased use of credit cards will definitely reduce the amount of cash that people will carry and as a consequence, reduce the risk and the cost associated with that.

\section{Payment Banks in Financial Inclusion:}

Payment Banks role is also very important when considered from the perspective of financial inclusion.

\section{M-Banking:}

Someone could fill cash into an m-Commerce bank account in one place, and who holds the debit card could withdraw cash from any ATM frictionless from any other place. Even can withdraw or pay in a more rural location, through any point of sale terminal with a "business correspondent", essentially an authorised partner for the bank. It's these partners - and theoretically the small convenience shop in a village that sells mobile recharges, Kirana shops, fruit shop could be among them - that will serve the purpose of bank branches, though the payment banks can set up branches if they want.

\section{The Department of Posts:}

The Department of Posts is also important for that same reason - the Department of Posts can reach every village, and connect farmers to banks. Think of the huge number of government subsidies and cash programs that are meant to encourage development in villages, and consider how, to access these payments, villagers would have had to travel for hours to nearby cities in order to visit a bank branch, where the experience was frequently alienating. Instead, the friendly postman you meet every day could be your banking relationship manager.

India Post has about 1,54,000 post offices, of them $90 \%$ are in rural areas. There is one post office for every 7176 people in India. India Post also has 2,96,000 agents in the rural area. About 2.2 crore people, 
already receive their National Rural Employment Guarantee Act (NREGA) payments by post offices. After State Bank of India, India Post has the largest deposits valued at Rs. 6 lakh crore.

\section{Pradhan Mantri Jan-Dhan Yojana (PMJDY):}

PMJDY is India's National Mission for Financial Inclusion to ensure access to financial services, namely Banking Savings \& Deposit Accounts, Remittance, Credit, Insurance, Pension in an affordable manner. It was launched by the Prime Minister of India Narendra Modi on 28 August 2014. He had announced this scheme on his first Independence Day speech on 15 August 2014.

It runs by Department of Financial Services, Ministry of Finance. 1.5 Crore (15 million) bank accounts were opened under this scheme on the day of inauguration. By 1 June 2016, over 22 crore (220 million) bank accounts were opened and Rs. 384.11 billion (US\$5.7 billion) were deposited under the scheme.

Table 1: The details of accounts open under PMJDY scheme:

\begin{tabular}{|c|c|c|c|c|c|c|c|c|}
\hline \multirow[t]{2}{*}{$\begin{array}{l}\text { S. } \\
\text { No. }\end{array}$} & & \multicolumn{3}{|c|}{ Number of Accounts } & \multirow[t]{2}{*}{$\begin{array}{l}\text { Number } \\
\text { of RuPay Cards }\end{array}$} & \multirow[t]{2}{*}{$\begin{array}{l}\text { Aadhaar } \\
\text { Seeded } \\
\end{array}$} & \multirow[t]{2}{*}{$\begin{array}{ll}\text { Balance } & \text { in } \\
\text { Accounts } & \\
\end{array}$} & \multirow[t]{2}{*}{$\begin{array}{l}\% \text { of Zero } \\
\text { Balance } \\
\text { Accounts } \\
\end{array}$} \\
\hline & & Rural & Urban & Total & & & & \\
\hline 1 & $\begin{array}{l}\text { Public } \\
\text { Sector } \\
\text { Banks }\end{array}$ & 11.74 & 9.43 & 21.17 & 16.75 & 12.54 & $54,507.02$ & $25.08 \%$ \\
\hline 2 & $\begin{array}{l}\text { Region } \\
\text { al Rural } \\
\text { Banks } \\
\end{array}$ & 3.86 & 0.61 & 4.47 & 3.36 & 2.26 & $12,976.71$ & $20.53 \%$ \\
\hline 3 & $\begin{array}{l}\text { Private } \\
\text { Banks }\end{array}$ & 0.52 & 0.35 & 0.87 & 0.82 & 0.39 & $2,587.07$ & $33.92 \%$ \\
\hline & Total & 16.11 & 10.4 & 26.51 & 20.93 & 15.19 & $\begin{array}{l}70,070.79 \text { crore (US } \\
\$ 10 \text { billion) }\end{array}$ & $24.61 \%$ \\
\hline
\end{tabular}

"Statistical Tables Related to Banks in India - Reserve Bank of India"

\section{The India Post Payments Bank (IPPB):}

IPPB has been recently incorporated as a Public Limited Company under the Department of Posts with $100 \%$ GOI equity.

IPPB will offer demand deposits such as savings and current accounts up to a balance of Rs 1 Lac, digitally enabled payments and remittance services of all kinds between entities and individuals. In partnership with insurance companies, mutual fund houses, pension providers, banks, international money transfer organisations etc. it also provide access to third party financial services such as insurance, mutual funds, pension, credit products, forex and so on.

\section{The key features of IPPB are:}

(i) Financial Literacy: IPPB is formed to ensure every individual has equal access to financial information and services irrespective of their individual status and region and to make India prosperous by wealth creates. Even a little saving can go a long way if it correctly channelized. With trustworthy advice and services designed to include everybody, income can be invested correctly, more can be saved, and people can start moving forward, faster.

(ii) Streamlining Payments: Beneficiaries can access income from government's DBT programs like MNREGA wages, Social Security Pensions and scholarships, directly from their IPPB bank account with near zero friction. They can also pay their utility bills, fees for educational 
institutions and many more from the same IPPB account. It ensures that wherever they are, they can make the most of financial opportunities available to them.

(iii) Ease of Accessibility: IPPB is powered by the very postmen who deliver our letters. With over 1.54 lac post offices across the country, India Post enjoys the trust of Indians everywhere. The postal delivery system will make IPPB, India's most accessible banking network. IPPB will also offer services through internet and mobile banking, and prepaid instruments like mobile wallets, debit cards, ATMs, PoS and MPoS terminals etc.

\section{Conclusion:}

With the advent of computers and electronic communications a large number of alternative electronic payment systems have emerged. These include debit cards, credit cards, electronic funds transfers, direct credits, direct debits, internet banking and e-commerce payment systems. Some payment systems include credit mechanisms, but that is essentially a different aspect of payment. Payment systems are used in lieu of tendering cash in domestic and international transactions and consist of a major service provided by banks and other financial institutions.

Millions of Indians don't have access to banking facilities. They cannot avail of government benefits, loans and insurance, and even interest on savings. M- Banking, PMJDY and IPPB will reach the unbanked and the under-banked across all cross sections of society and geographies.

\section{References:}

1. News Papers and websites :

The Economic Times, Business Line and The Times of India.

2. http://www.rbi.org.in 